\title{
POST-PRAWDA, PRAWDA I COŚ JESZCZE W KONCEPCJI STANÓW ZJEDNOCZONYCH EUROPY PRZEDSTAWIONEJ W CZASOPIŚMIE OPOKA W KRAJU
}

\author{
POST-TRUTH, TRUTH AND SOMETHING MORE \\ IN THE CONCEPT OF THE UNITED STATES OF EUROPE \\ PRESENTED IN THE MAGAZINE OPOKA W KRAIU
}

\author{
Marcin Płoski* ()
}

\begin{abstract}
- ABSTRAKT
Czasopismo Opoka w Kraju redagowane jest przez profesora Macieja Giertycha, który w swoich artykułach porusza różnorakie kwestie: począwszy od konfliktu cywilizacji, kończąc na problematyce integracji europejskiej. Jednakże kwestia Stanów Zjednoczonych Europy, której Maciej Giertych przeciwstawia ideę Europy Ojczyzn, budzi uzasadnione kontrowersje, ponieważ w krytyce tej pierwszej posługuje się retoryką, która często odnosi się do ingerencji masonów w wewnętrzne sprawy integracji europejskiej. Zasadniczym celem artykułu jest wyodrębnienie zwłaszcza tych zagadnień, które budzą wątpliwości ze względu na brak wystarczającego ich udokumentowania. Maciej Giertych w swojej publicystyce podjął nierówną grę z organizacjami masońskimi, które ze względu na swój ezoteryzm nie mają w zwyczaju wchodzić w polemiki, dyskusje czy recenzować opinii swoich adwersarzy.
\end{abstract}

The magazine Opoka w Kraju is edited by Professor Maciej Giertych, who discusses various issues in his articles: from the conflict of civilizations to the problems of European integration. However, the question of the United States of Europe, which in Maciej Giertych's view opposes the idea of a European Fatherland, raises a justified controversy, because in the criticism of the former topic, Professor Giertych uses rhetoric which frequently refers to the interference of Freemasons in the internal matters of European integration. The main aim of the article is to isolate especially those issues which raise doubts due to the lack of sufficient documentation. Maciej Giertych, in this political journalism, undertook an unequal competition with Masonic organizations, which due to their esotericism are not in the habit of entering into polemics, discussing or reviewing the opinions of their adversaries. In this situa-

* Uniwersytet Wrocławski, Wydział Nauk Społecznych. 
W tej sytuacji otrzymujemy jednostronny przekaz prezentowany w Opoce w Kraju.

Słowa kluczowe: Maciej Giertych; Opoka $w$ Kraju; Stany Zjednoczone Europy; masoneria; spiski masońskie; post-prawda tion, we receive a unilateral message presented in Opoka w Kraju.

Keywords: Maciej Giertych; Opoka w Kraju; United States of Europe; Freemasonry; Masonic conspiracy; post-truth

\section{WSTĘP}

Problematyka Stanów Zjednoczonych Europy jest często poruszanym zagadnieniem w publicystyce Macieja Giertycha, który redaguje czasopismo Opoka $w$ Kraju. Jest ono adresowane przede wszystkim do czytelnika o poglądach prawicowych, szczególnie do odbiorców, którzy związani są z ruchami i organizacjami narodowymi. Czasopismo Opoka w Kraju trafia również do środowisk związanych z Kościołem katolickim.

Zagadnienie Stanów Zjednoczonych Europy jest poruszane w artykułach wspomnianego czasopisma w sposób niechronologiczny, toteż przytaczane fragmenty jego artykułów będą porządkowane tak, aby stanowiły merytorycznie spoistą koncepcję.

Owa problematyka budzi w środowiskach prawicowych uzasadnione kontrowersje. Można wyróżnić dwie grupy: entuzjastów i sceptyków przedstawianej przez Macieja Giertycha koncepcji. Celem niniejszego artykułu jest jednak przedstawienie tego zagadnienia bez opowiadania się po którejkolwiek stronie, lecz obiektywne ukazanie jego metodologicznych aspektów. Dlatego artykuł będzie miał formę analizy materiałów prasowych, a jego zasadniczym celem będzie udzielenie odpowiedzi na następujące pytanie badawcze: czy koncepcja Stanów Zjednoczonych Europy prezentowana przez Macieja Giertycha posiada znamiona naukowości? Pytanie to wpisuje się w motto, które mu towarzyszy, a mianowicie: „Post-prawda. Między prawdą, nieprawdą i czymś jeszcze”. Dla potrzeb niniejszego artykułu konieczne było w związku z tym przedstawienie definicji post-prawdy, która będzie determinowała w dalszej części wywodu to, co jest oparte na przesłankach naukowych i nienaukowych w koncepcji zaprezentowanej przez Macieja Giertycha. Post-prawda jest zatem „okolicznościami w kulturze politycznej, w których obiektywne fakty mają mniejszy wpływ na kształtowanie opinii publicznej, niż odwoływanie się do emocji i osobistych przekonań”"

1 Post-truth, Pobrane z: https://en.oxforddictionaries.com/definition/post-truth. 
W rozważaniach nad koncepcją Stanów Zjednoczonych Europy będzie miało znaczenie to, jak jest ona ukazywana na gruncie europeistyki i w artykułach Macieja Giertycha, który po części powołuje się na prądy myślowe, które były udziałem - w jego mniemaniu - masonerii. W publicystyce Maciej Giertych posługuje się specyficzną nomenklaturą naukową, a mianowicie nie dokonuje rozgraniczenia koncepcji federacyjnej Europy Konrada Adenauera od koncepcji Stanów Zjednoczonych Europy, stosowanej przez masonerię, a więc według Macieja Giertycha koncepcja federacyjna i koncepcja Stanów Zjednoczonych Europy oznacza to samo. Jednakże na gruncie europeistyki i masologii (nauki o masonerii, subdyscyplinie nauk historycznych) wiemy, że istnieją w tej materii pewne niuanse, które zaprezentuję w toku dalszych rozważań. Jednocześnie, aby nie wprowadzać chaosu terminologicznego, będę posługiwał się terminologią wprowadzoną przez Macieja Giertycha, czyli terminem Stany Zjednoczone Europy.

\section{KONCEPCJA STANÓW ZJEDNOCZONYCH EUROPY KONRADA ADENAUERA NA GRUNCIE EUROPEISTYKI}

Konrad Adenauer uważał, że zjednoczenie Europy nie nastąpi na skutek jednego procesu zjednoczeniowego z zamkniętym horyzontem czasowym, który łatwo da się przewidzieć. W jego koncepcji Europa jednoczyć będzie się stopniowo, a proces ten przebiegać będzie w sposób, który można by określić jako permanentną ewolucję. Konrad Adenauer postrzegał Europę jako organizm unitarny (federalny), który kończy proces integracji na zasadzie konfederacji (związku państw). „Kanclerz natomiast pozostawał pod wpływem wizji federalistycznych i postulował, aby państwa zachodnioeuropejskie zrzekły się swej suwerenności na rzecz jednego europejskiego państwa związkowego - miały to być Stany Zjednoczone Europy. Struktura ta charakteryzowałaby się uniwersalizmem politycznym, służącym przezwyciężeniu narosłych w przeszłości konfliktów i antagonizmów na tle państwowym, narodowym oraz gospodarczym. W zamyśle Adenauera powstanie Stanów Zjednoczonych Europy było uzależnione od odbudowania europejskiej wspólnoty narodów, w której każdy naród wniósłby swój konieczny wkład do europejskiej cywilizacji” (Białas-Zielińska, 2011).

Istotne znaczenie w tak zjednoczonej Europie miał stanowić tandem państw, czyli Niemcy i Francja. W swoim zamyśle miało to w przyszłości niwelować konflikty europejskie, zwłaszcza militarne. 
Kanclerz Adenauer w zasadzie prezentował w swojej koncepcji 'integralny federalizm', który w swej istocie zasadzał się na federalnej strukturze Europy, w którą miały być wmontowane federalne struktury jej narodowych członków. Dlatego niemiecka federacja miała być pierwowzorem dla innych narodów tworzących Europę.

Inne założenia koncepcji Konrada Adenauera to stwierdzenie, że Europa nie była pojęciem geograficznym, ale pojęciem ideowo-politycznym, które jest oparte na takich wartościach jak: filozofia grecka, prawo rzymskie oraz idee Oświecenia. Dla Adenauera Europa oznaczała socjalną gospodarkę rynkową.

Bardzo istotnym akcentem w politycznym testamencie Konrada Adenauera było jego wystąpienie na konferencji w Madrycie w dniu 16 lutego 1967 roku, na krótko przed swoją śmiercią. Przedstawił on geopolityczną wizję ówczesnego świata, który był podzielony między Stany Zjednoczone Ameryki Północnej, Związek Radziecki, Chińską Republikę Ludową i Europę. Zaznaczył on w swoim przemówieniu, iż Europa została ubezwłasnowolniona przez pozostałe mocarstwa, które dysponują bronią atomową i jej nośnikami. Taka nierównowaga w stosunkach międzynarodowych prowadzi, według niego, do podporządkowania Europy tym trzem mocarstwom. Nasuwa się w związku z tym konstatacja, iż Konrad Adenauer chciał zapobiec istnieniu tej nierównowagi, zwłaszcza w sferze militarnej poprzez postulat stworzenia Europejskiej Wspólnoty Obronnej, która w efekcie nie doczekała się realizacji.

\section{STANY ZJEDNOCZONE EUROPY JAKO KONCEPCJA MASOŃSKA}

Maciej Giertych rozpoczyna swoje rozważania dotyczące koncepcji integracji europejskiej od Francji, a szczególnie od momentu Wielkiej Rewolucji Francuskiej. Bez wątpienia ma on rację, gdy stwierdza, iż Unia Europejska wyrosła na wartościach Wielkiej Rewolucji Francuskiej. Niewątpliwie w sferze wartości Unia Europejska zbudowana jest na republikańskich zasadach rewolucji francuskiej: „Francja jest przekonana, że odgrywa przemożną rolę w kształtowaniu ideologicznym Unii Europejskiej poprzez wpływy masońskie. Jest w tym sporo prawdy. To głównie ona oponuje przeciwko wstawieniu wzmianki o chrześcijaństwie do konstytucji europejskiej. Jak słusznie zauważa Arnaud de Lassus, Unia Europejska budowana jest na Rewolucji Francuskiej, na zasadach republikańskich, dziedzictwie Oświecenia, prawach człowieka z 1789 r. Nie ma porządku nadprzyrodzonego, objawionego wszystkim - każdy wybiera sobie religię według 
własnego upodobania. Faktycznie hołduje się okultyzmowi, czyli religii Szatana" (Giertych, 2003a).

Maciej Giertych podkreśla w swoich badaniach, iż we Francji masoneria jest traktowana w szczególnie uprzywilejowany sposób, niewspółmiernie do innych instytucji reprezentujących inne wartości, np. chrześcijańskie, co wynika przede wszystkim ze świeckiego charakteru tego państwa oraz faktycznego, a nie tylko literalnego, rozdziału państwa od Kościoła:„ „Okazuje się, że mimo rzekomych różnic i rywalizacji jest coś takiego jak Grand Collège des Rites», czyli wyższa masoneria tajna (Haute Maçonnerie secrète) skupiająca najwyższych rangą masonów różnych rytów. W swoim przemówieniu do nich Chirac dziękował masonom za ich «ważny wkład w opracowanie i promowanie idei republikańskich», za ich «czynną rolę w obronie i potwierdzaniu zasad republikańskich», za ich «wkład w narodzenie się III Republiki» i za ich «kluczową rolę w zakorzenianiu ideału republikańskiego we Francji». Innymi słowy republika to masoneria. Obowiązujący we Francji od 1905 roku rozdział Kościoła i Państwa jest ściśle przestrzegany. Między religią masońską a państwem żadnego rozdziału nie ma" (Giertych, 2003a).

Maciej Giertych ekstrapoluje myśl masońską na Wielką Rewolucję Francuską, skoro można przyjąć, że jej przywódcy, Jean-Paul Marat i Georges Jacques Danton, byli masonami, to ona sama i jej idee były wytworem masonerii. Należy podkreślić, iż w tamtym okresie w zwołanej przez króla Ludwika XVI Burbona w 1789 roku Konstytuancie było według Jeana Ousseta 477 masonów (por. Baszkiewicz, 1990). Okres tuż przed Wielką Rewolucją Francuską i w czasie jej trwania był okolicznością sprzyjającą gwałtownemu rozwojowi liczebnemu masonerii we Francji. Z kolei Jean Ousset uważa, iż w tamtym okresie, tj. od 1789 roku, wszystkie siły napędowe we Francji wpadają w ręce masonów (Ousset, 1986). Wielu badaczy wskazuje, iż był jakiś wpływ masonerii na Wielką Rewolucję Francuską, choćby ze względu na fakt jej liczebnego rozrostu w tamtym okresie. Nie wszyscy przywódcy Wielkiej Rewolucji Francuskiej w tamtym okresie byli masonami. Do pewnego stopnia można uznać, że koncepcje republikańskie i masońskie w tamtym czasie wzajemnie się przenikały. W związku z tym trudno jest oddzielić to co masońskie od tego, co republikańskie. Maciej Giertych próbuje w swojej retoryce narzucić narrację, iż to bezapelacyjnie masoneria miała w tym względzie decydujący wpływ. Niewątpliwie jest to daleko idące uogólnienie tego zagadnienia.

Masoneria była obecna zarówno w środowiskach politycznych związanych z królem Ludwikiem XVI Burbonem, jak i uczestniczyła w Wielkiej Rewolucji Francuskiej, której celem było obalenie władzy monarszej. 
Drugą kwestią poruszaną przez Macieja Giertycha jest świecki charakter zdobyczy Wielkiej Rewolucji Francuskiej, co kłóci się z jego światopoglądem. W tej sytuacji przeciwstawia on wartości Wielkiej Rewolucji Francuskiej: wolność, równość, braterstwo - wartościom chrześcijańskim, określając je jako nieprzystające jedne do drugich, o czym świadczą jego słowa: „Po wizycie w Brukseli grupy polskich biskupów abp. Henryk Muszyński przyznał, że Kościół w pełni uznaje wartości wypisane na sztandarach rewolucji francuskiej: «równość, wolność i braterstwo, które w istocie są wartościami głęboko chrześcijańskimi». Będziemy działać na rzecz zjednoczenia z Unią Europejską - zadeklarował sekretarz Episkopatu Polski bp. Tadeusz Pieronek. Przypomnijmy, że rewolucję i hasła te dała masoneria, a nie chrześcijanie" (Giertych, 1998).

W badaniach nad kwestią Stanów Zjednoczonych Europy a federalizmem europejskim zaznaczają się rozbieżności, których nie dostrzega Maciej Giertych. W swojej publicystyce zakłada on, iż Stany Zjednoczone Europy i federalizm europejski Konrada Adenauera to w istocie to samo. Wątpliwości co do tych zasadniczych kwestii rozwiewa Pierre Virion, który stwierdza: „Ujmując najogólniej, idea Stanów Zjednoczonych Europy polega na stworzeniu jednego i jedynego rządu rozciągającego swą władzę na wszystkie narody europejskie przemienione w wielkie prowincje. Natomiast federalizm europejski zmierza raczej do rządu, który byłby jedynie emanacją rządów poszczególnych narodów istniejących nadal w swej własnej formie. Miałby on władzę bardziej ograniczoną [...]"(Virion, 1999). Obecnie Unia Europejska ma hybrydalny charakter, tzn. łączy w sobie niektóre cechy państw narodowych z koncepcji Europy Ojczyzn, której twórcą był Charles de Gaulle, oraz z adenauerowskiej federacyjnej koncepcji Europy. Kolejne traktaty europejskie coraz bardziej zbliżają Unię Europejską do federacji, lecz obecnie nie stała się ona jeszcze federacją. Jednak, jeśli Unia Europejska nie stanie się federacją, to grozi jej rozpad. Faktem historycznym jest to, iż wszystkie unie: personalne, realne, polityczne i gospodarcze w przeszłości zawsze rozpadały się (por. Płoski, 2016a).

Maciej Giertych w swoich badaniach nad Stanami Zjednoczonymi Europy zauważa, iż koncepcja ta powstała w wyniku spisku masońskiego. Jednak należy zaznaczyć, iż jest ona tylko przyczynkiem do powstania republiki światowej z jednym rządem światowym, o czym świadczą słowa: „Utworzenie przestrzeni europejskiej - pisze Jacąues Ploncard d'Assac - jest dla masonów tylko zapowiedzią przestrzeni uniwersalnej, Ziemi - Ojczyzny”. Wielki mistrz Wielkiej Loży Francji, Guy Piau, potwierdza to: „Zabieganie o wspólnotę europejską, a następnie uniwersalną, wchodzi oczywiście w zakres naszych studiów i naszych działań" 
(Points de vue initiatiąues, 1989, nr 72) „Republika uniwersalna”, „wspólnota uniwersalna” ...od Ramsaya aż do Guy Piau myśl masońska w tym punkcie nie uległa zmianie (Points de vue initiatiąues, 1989, nr 71). W mniemaniu Macieja Giertycha wpływ na powstanie koncepcji Stanów Zjednoczonych Europy mieli przede wszystkim masoni. Jednocześnie marginalizuje znaczenie faktycznych inicjatorów integracji Europejskiej: Alcide de Gaspariego, Roberta Schumana i Konrada Adenauera. W swoich wywodach sugeruje, iż na tę koncepcję mieli wpływ czołowi masoni z wielu państw europejskich, stwierdzając: „Euroentuzjaści wielokrotnie odwołują się do chadeckich korzeni UE, do jej rzekomych inicjatorów: Alcide de Gaspariego, Roberta Schumana i Konrada Adenauera. Jest to nieporozumienie. To nie jest chadecki pomysł. UE ma zupełnie inny rodowód. Niemiecki, ale też i masoński. Może warto przypomnieć, że w dniach 28-30.06.1917 roku, w siedzibie Grand Orientu w Paryżu odbyła się wielka międzynarodowa konferencja z udziałem lóż masońskich Francji, USA, Włoch, Belgii, Serbii i wielu innych krajów, ale bez udziału Anglii. Na wstępie tej konferencji podkreślano, że nie będzie tam miejsca na politykę, tylko na zagadnienia humanitarne, ale zaraz przystąpiono do politycznego ustawiania powojennego świata. Przede wszystkim zajmowano się konstytucją Ligi Narodów. Ustalono, że skoro Niemcom nie udało się zjednoczyć Europy, to trzeba powołać Federację Stanów Zjednoczonych Europy, zgodnie z teorią Mazziniego: «życie narodowe jest drogą, a międzynarodowe celem»" (Giertych, 2003b).

Masoni uważają projekt Ligi Narodów za własny. Podobnie jak koncepcja Stanów Zjednoczonych Europy był on tylko zaczynem do powstania w przyszłości jednego rządu światowego. Jak wyjaśnia to Leon de Poncins w dziele „Societe des Nations, super-Etat maconniąue” („Liga Narodów, masońskie superpaństwo”): „Liga Narodów odgrywała role jakby superpaństwa, którego zadaniem było podtrzymanie hegemonii masońskich zasad usankcjonowanych przez traktat wersalski” (de Poncins, 1942). Maciej Giertych zauważa, iż oba projekty, tj. Ligi Narodów i Stanów Zjednoczonych Europy, łączą w pośredni lub bezpośredni sposób nazwiska masonów: „Z Unii Paneuropejskiej i nieboszczki Ligi Narodów z czasem wyłonił się pomysł obecnej Unii Europejskiej. Łącznikiem był tu mason Jean Monnet (1888-1979), zausznik Schumana, pracownik Ligi Narodów i inicjator Komitetu Akcji na Rzecz Stanów Zjednoczonych Europy. Wtórował mu Józef Hieronim Retinger (1888-1960), agent wszelkich możliwych wywiadów, sekretarz Komitetu Koordynacji Międzynarodowych Ruchów na Rzecz Zjednoczenia Europy i inicjator tajnych spotkań faktycznego zakulisowego rządu światowego, czyli Klubu Bilderberg (dziś do niego zapraszany jest Andrzej Ole- 
chowski). Retinger działał z ramienia Winstona Churchilla (masona), który już w 1942 r. mówił o Stanach Zjednoczonych Europy, a 19.09.1946 r., przemawiając w Zurychu, rekomendował dla nich kantonalną strukturę, jak w Szwajcarii" (Giertych, 2003c).

Maciej Giertych podkreśla także znaczenie współpracy wysokiej rangi przedstawicieli Unii Europejskiej z organizacjami masońskimi. Zauważa, iż projekt europejski można uznać za punkt styczny władz Unii Europejskiej i masonerii, stąd bardzo przychylne stanowisko władz Unii Europejskiej do inicjatyw europejskich masonerii, o czym świadczą słowa: „Wszyscy posłowie do Parlamentu Europejskiego otrzymali pismo od pana Jean-Michel Quillardeta, Wielkiego Mistrza i Prezydenta Rady Wielkiego Wschodu Francji. W piśmie tym autor informuje nas o spotkaniu w dniach 20-22.VI.2008, w Atenach, II Masońskiego Zgromadzenia Międzynarodowego »Delphi« grupującego 40 obediencji masońskich. Tematem spotkania było »Budowanie Europy, budowaniem świata «. Do listu załączone są wnioski ze Zgromadzenia i adres Prezydenta Komisji Europejskiej José Manuela Barroso skierowany do jego uczestników. We wnioskach tych podkreślono, że był to pierwszy przypadek oficjalnego odniesienia się Prezydenta Komisji Europejskiej do organizacji masońskich. Barroso uznał rolę i wkład masonerii w rozwój społeczeństw i w promocję wartości europejskich na cały świat" (Giertych, 2009).

Maciej Giertych zauważa, iż masoneria w swoich działaniach proeuropejskich skwapliwie korzysta również z przywilejów, jakie dają organizacjom społecznym traktaty europejskie. W sposób pośredni dowodzi, iż przedstawiciele organizacji masońskich mają istotny wpływ na procesy decyzyjne w Unii Europejskiej, poprzez możliwość spotkania się z czołowymi przywódcami Unii Europejskiej. Należy to potraktować jednak jako tylko domniemanie, ponieważ nie mamy do dyspozycji stenogramów z rozmów między przedstawicielami Unii Europejskiej a masonami: „Przywódcy Unii Europejskiej, Komisji Europejskiej José Barroso, Rady Europejskiej Herman Van Rompuy i Parlamentu Europejskiego Jerzy Buzek spotkali się 15.X.2010 r. z przedstawicielami organizacji masońskich na trzygodzinnej rozmowie. Obliguje ich do takich spotkań art. 17\$2 i \$3 dodany do Traktatu ustanawiającego Europejską Wspólnotę przez Traktat Lizboński" (Giertych, 2010).

W publicystyce Macieja Giertycha rola Niemiec w integracji europejskiej schodzi na dalszy plan w stosunku do siły sprawczej masonerii w tej mierze. Niemniej należy również dostrzec ten głos $\mathrm{w}$ dyskursie zaproponowanym przez niego. Dostrzegalne jest tu pewne zróżnicowanie ról poszczególnych państw 
graczy na europejskiej scenie politycznej. O ile rola Francji jest identyfikowana $\mathrm{z}$ wpływami masońskimi na przebieg integracji europejskiej - bardziej w sferze aksjologicznej, o tyle Niemcy postrzegani są jako kraj, który swoje wpływy w scalaniu Europy na modłę adenauerowskiej federacji zbudowały na sile swojej gospodarki i finansjery. „Drugi filar Unii Europejskiej to Niemcy, którzy oddziaływują poprzez siłę swojej gospodarki i prężność organizacyjną. Okazując tradycyjną pogardę wobec pokonanych, Niemcy, jako główny płatnik Unii, zaplecze finansowe euro i silna armia coraz częściej narzucają swoją wolę pozostałym członkom. Krok po kroku realizują rozpoczęty przez Bismarcka plan podporządkowania Prusom całej Europy. Zaczynając od obszaru wolnocłowego, a kończąc na strukturze federalnej ze zdominowanym przez siebie rządem centralnym, stopniowo realizują swe odwieczne marzenia dominowania nad Europą. Wnet się przekonamy, że niemiecka nadrzędność nie jest milsza od sowieckiej” (Giertych, 2010).

Maciej Giertych nie omieszkał, omawiając koncepcje masońskie, odwołać się do wątku polskiego tej kwestii, a mianowicie rozpatruje on podatność Polaków na wpływy masońskie z pozycji narodowca oraz z perspektywy polonocentrycznej. W okresie PRL-u masoneria działała w głębokiej konspiracji ze względu na walkę reżimu komunistycznego z masonerią. Niewątpliwie po 1989 roku w Polsce nastąpił nagły przyrost organizacji masońskich i paramasońskich. Maciej Giertych jednoznacznie twierdzi, że masoneria i organizacje paramasońskie w Polsce są reprezentantami „obcych” interesów. „Program narodowy musi być oparty wyłącznie na ocenie tego, co jest dobre dla Polski. Innymi słowy nie można się oglądać na to, co o tym sądzą za granicą. Wszelkie sugestie, zalecenia, dyrektywy czy naciski, płynące z zagranicy, nie mają na względzie naszych interesów, a więc w ogóle nie należy ich brać pod uwagę przy podejmowaniu decyzji. Dlatego tak bardzo ryzykownym jest włączanie w proces decyzyjny osób, reprezentujących interesy obce. Chodzi zarówno o pracowników międzynarodowych korporacji, jak i o posiadających obce obywatelstwa, czy też należących do tajnych lub półtajnych międzynarodowych gremiów, takich jak masoneria, kluby Bilderberg, Komisja Trójstronna, Rotary, Lions i inne. Ludzie tacy z reguły myślą bardziej internacjonalistycznie niż narodowo. Są podatni na podszepty obcych interesów" (Giertych, 2005).

W Opoce $w$ Kraju podejrzliwie podchodzono do sprawy podziału administracyjnego kraju z 1998 roku, a więc podziału Polski na 16 województw i utworzenie powiatów - trzeciego stopnia administracji. Maciej Giertych ocenia tę koncepcję krytycznie, określając ją jako landyzację Polski, a więc przypisuje 
polskiemu rządowi intencje stworzenia federacyjnego podziału administracyjnego państwa polskiego na wzór podziału administracyjnego Niemiec, który jest bliski masońskiej koncepcji Stanów Zjednoczonych Europy. Jest to niewątpliwie nieporozumienie, ponieważ reforma administracyjna w swej zasadniczej mierze odwracała gierkowską reformę administracyjną, w której województwa stały się tak naprawdę sztucznymi tworami administracyjnymi, bo jak można określić istnienie karłowatych województw, np. ostrołęckiego, kaliskiego i wielu innych, o niewielkim potencjale demograficznym, gospodarczym, naukowym etc. Przeprowadzona w roku 1998 reforma terytorialna i ustrojowa państwa, a zwłaszcza utworzenie nowych 16 dużych województw, stworzyło podstawy instytucjonalne dla spełnienia celów i zadań polityki regionalnej w ramach europejskiej polityki regionalnej. Np. art. 158 Traktatu ustanawiającego Wspólnotę Europejską (Dz. U. z 2004 r. Nr 90, poz. 864/2 z późn. zm.) wskazuje, że jednym z celów Wspólnoty jest jej harmonijny rozwój służący wzmocnieniu jej spójności gospodarczej i społecznej oraz zmniejszeniu dysproporcji w poziomach rozwoju różnych regionów, czy wręcz zacofaniu niektórych z nich, zwłaszcza obszarów wiejskich. Polityka spójności powinna przyczyniać się do wzrostu gospodarczego, zwiększenia konkurencyjności i zatrudnienia, dla jej realizacji ustanowiono Fundusz Spójności, Europejski Fundusz Rozwoju Regionalnego i Europejski Fundusz Społeczny, Europejski Fundusz Rolny na rzecz Obszarów Wiejskich oraz Europejski Fundusz Rybołówstwa. Dla realizacji trzech pierwszych wydane zostało rozporządzenie Rady (WE) nr 1083/2006 z dnia 11 lipca 2006 roku, ustanawiające przepisy ogólne dotyczące Europejskiego Funduszu Rozwoju Regionalnego, Europejskiego Funduszu Społecznego oraz Funduszu Spójności i uchylająca rozporządzenie (WE) nr 1260/1999 (Dz. U. UE L z 2006 r. Nr 210, poz. 25).

„Jeżeli władza jest mocna, pozwala sobie na decentralizację, co prowadzi do rozbudowania struktury terytorialnej, która umożliwia decentralizację, kreując jej podmioty terytorialne. Władza słaba dąży do centralizacji, którą łatwiej realizować w układzie uproszczonym. Podział trójstopniowy był w Polsce znany i stosowany od wieków. Jedynie w okresach niewoli okupant narzucał własne podziały terytorialne, obce państwowości polskiej. W 1975 r. ówczesne władze socjalistycznego państwa dokonały zmiany podziału terytorialnego państwa z trójstopniowego na dwustopniowy. Przeprowadzano go pod hasłem »władza bliżej obywatela«, w rzeczywistości jednak zabieg ten był skierowany przeciw obywatelowi. Likwidacja powiatów i utworzenie 49 województw nie przybliżyło władzy do obywatela, a raczej ją oddaliło, większość bowiem decyzji podejmo- 
wanych przez małe województwa wymagało uzgodnień z władzą centralną. $\mathrm{W}$ dodatku podział przeprowadzono wbrew jakimkolwiek zasadom tworzenia jednostek podziału terytorialnego, niszcząc dotychczasowe struktury społeczne, gospodarcze i kulturowe" (Chrisidu-Budnik, Korczak, 2013). Oto pogląd, który w tej materii prezentuje Maciej Giertych: „Komentując separatyzmy Szkocji, Walii, Śląska itd. prof. Andrzej Piskozub z Uniwersytetu Gdańskiego twierdzi, że «Dezintegracja państw Europy jest procesem ozdrowieńczym, który w przyszłości doprowadzi do integracji Europy jako całości». Gazeta Wyborcza coraz to jakiś makroregion zachwala, podkreślając jego historyczne racje (np. 7.X.97 r. pisała rzewnie o aktualności Galicji). Program podziału Polski na makroregiony (co się nagłaśnia pod hasłem powrotu do powiatów) ma na celu ułatwienie dezintegracji (landyzacji) Polski, by w zjednoczonej Europie był kiedyś tylko rząd federalny i rządy regionów. W masońskich planach rządu światowego nie ma miejsca dla rządów państw narodowych, które trzeba stopniowo zdyskredytować i wyeliminować” (Giertych, 1997).

W związku z tym nasuwa się zasadnicze pytanie: co jest post-prawdą i prawdą w koncepcji Stanów Zjednoczonych Europy prof. Macieja Giertycha? Dokonano również próby odpowiedzi: czy oprócz post-prawdy i prawdy jest coś jeszcze? Odpowiedź na te pytania zamieszczona została w formie zestawienia tabelarycznego.

Tabela 1. Post-prawda, prawda i coś jeszcze w koncepcjach Stanów Zjednoczonych Europy prezentowanych przez Macieja Giertycha

\begin{tabular}{|l|l|}
\hline & $\begin{array}{l}\text { - Dokonanie zabiegu semantycznego polegającego na zamianie podmiotu spraw- } \\
\text { czego odnośnie integracji europejskiej z Alcide de Gaspariego, Roberta Schumana } \\
\text { i Konrada Adenauera na masonów i Niemców. } \\
\text { - Przyjęcie, że twórcą koncepcji Stanów Zjednoczonych Europy (koncepcji federa- } \\
\text { cyjnej) nie był Konrad Adenauer, lecz masoni. }\end{array}$ \\
$\begin{array}{l}\text { Co jest post-praw- } \\
\text { dą w koncepcjach } \\
\text { prezentowanych } \\
\text { przez Macieja } \\
\text { Giertycha? }\end{array}$ & $\begin{array}{l}\text { braterstwo była wytworem masonów. } \\
\text { - Założenie, że skoro podstawą Wielkiej Rewolucji Francuskiej i jej ideałów: } \\
\text { wolność, równość, braterstwo, była myśl masońska, a Unia Europejska wyrosła na } \\
\text { tych ideałach, to Unia Europejska jest koncepcją masońską. } \\
\text { - Założenie, że masońska koncepcja Stanów Zjednoczonych Europy to to samo co } \\
\text { koncepcja federacyjna Konrada Adenauera. } \\
\text { - Założenie, że reforma administracyjna Polski w } 1998 \text { r. miała na celu utworzenie } \\
\text { federalnej struktury państwa polskiego na kształt podziału administracyjnego } \\
\text { Niemiec, co ma wynikać z planów masońskich stworzenia rządu światowego. }\end{array}$ \\
\hline
\end{tabular}




\begin{tabular}{|c|c|}
\hline $\begin{array}{l}\text { Czy oprócz post- } \\
\text {-prawdy jest coś } \\
\text { jeszcze? }\end{array}$ & $\begin{array}{l}\text { - różnego rodzaje spekulacje } \\
\text { - różnego rodzaju domniemania, przypuszczenia, domysły } \\
\text { - } \text { spiski masońskie }\end{array}$ \\
\hline $\begin{array}{l}\text { Co jest prawdą } \\
\text { w koncepcjach } \\
\text { prezentowanych } \\
\text { przez Macieja } \\
\text { Giertycha? }\end{array}$ & $\begin{array}{l}\text { Wszystkie spotkania masonów we własnym gronie, a także z reprezentantami władz } \\
\text { różnych krajów oraz z wysokiej rangi przedstawicielami władz Unii Europejskiej, } \\
\text { jednakże trudno ocenić wpływ masonów na ich decyzje, ponieważ nikomu nie } \\
\text { udało się zbadać naukowo tego zagadnienia, ze względu na półtajny charakter } \\
\text { masonerii. }\end{array}$ \\
\hline
\end{tabular}

Źródło: opracowanie własne.

\section{PODSUMOWANIE}

Wszystkie organizacje tajne i półtajne mają jedną wspólną cechę, a mianowicie wszelkie informacje pochodzące od nich zazwyczaj nie są autoryzowane przez ich członków, stąd w wielu przypadkach nie wiemy, kto jest twórcą jakiejś koncepcji. Najczęściej bywa tak, iż dowiadujemy się, że za jakąś teorią, np. dotyczącej Stanów Zjednoczonych Europy, stoi taka czy inna obediencja masonerii. Jest to jedna z zasadniczych przyczyn, dlaczego masońskie koncepcje integracji europejskiej nie zostały implementowane przez naukę, a w szczególności przez europeistykę. Czasami tylko dowiadujemy się, że jakaś teoria integracji europejskiej jest stworzona przez myśliciela, który jednocześnie był masonem, ale $\mathrm{z}$ tego nie wynika fakt, że akurat tę teorię można przypisać konkretnie masonerii. Jest to tym trudniejsze, gdyż sama masoneria nie stanowiła nigdy monolitu. W jej skład wchodzi wiele organizacji o zróżnicowanym zapleczu intelektualnym. Podobne stanowisko prezentuje Ludwik Hass, który twierdzi, że „sztuka królewska przeżywała w ciągu ponad ćwierćtysiąclecia swego istnienia różnokierunkową ewolucję. Podzieliła się ona na wyraźnie wyodrębnione odłamy-nurty (...) niekiedy wręcz nawzajem negujące swój wolnomularski charakter. Mimo to nadal stanowi, przynajmniej dla patrzących na nią z zewnątrz, określoną całość” (Hass, 1993).

Jak zauważa Piotr Grabowiec, Stany Zjednoczone Europy są jedną z wielu koncepcji masońskich, ale nie jest ona najważniejsza, ponieważ „głównym (...) celem wolnomularstwa jest zjednoczenie całej ludzkości w formie powszechnej republiki obejmującej cały świat. Dążyć należy, zdaniem masonerii, do utworzenia stanów zjednoczonych świata. Praktyczna działalność masonerii w osiągnięciu celu przyniosła trzy inicjatywy: zawiązanie Ligi Narodów, inicjatywa jej reformy oraz koncepcja Stanów Zjednoczonych Europy (Paneuropa)" (Grabowiec, 1998). 
Bronisław Malinowski zalicza masonerię do instytucji społecznych na równi z: rodziną, zalotami, grupą sąsiedzką, miastem, czarownikami, szpitalem dla umysłowo chorych, państwem, narodem (por. Malinowski, 1958). Wydaje się to bardzo szerokim podejściem terminologicznym do kwestii masonerii. Niewątpliwie masoneria zalicza się do zrzeszeń. Według klasyfikacji Murray’a Hausknechta, dzieli on zrzeszenia na: „1) obywatelskie i usługowe (civic and service), 2) loże i bractwa, 3) kościół i związki religijne (church and religions), 4) społeczne (towarzyskie) i rekreacyjne, 5) zrzeszenia weteranów, wojskowe i patriotyczne, 6) ekonomiczne, zawodowe i profesjonalne, 7) kulturalne, wychowawcze i wychowanków, 8) polityczne i nacisku (pressure)" (Hausknecht, 1962). Według historyka Bernarda Lazare „stowarzyszenia sekretne reprezentują dwie strony judaistycznego ducha: racjonalizm praktyczny i panteizm" (de Lassus, 1993).

Bez wątpienia problem $z$ implementacją teorii integracji europejskiej wynikał również z tego, że masoneria jeszcze w niedalekiej przeszłości była organizacją tajną. Obecnie podkreśla się jej półtajny charakter. Taka sytuacja nie jest sprzyjająca rozwojowi naukowemu, a tym bardziej adaptowaniu koncepcji masońskich przez naukę, w tym szczególnie europeistykę. Trudno sobie wyobrazić „robienie nauki” w ukryciu, gdzieś zza węgła. Nauka opiera się na pytaniach badawczych, hipotezach, tezach i ich potwierdzaniu lub obalaniu, na prowadzeniu otwartej dyskusji akademickiej ze wszystkimi jej konsekwencjami. Koncepcje masońskie w związku z tym musiałyby być poddane dyskusji, polemice i recenzji środowiska naukowego, na co nie jest z kolei otwarta masoneria, gdyż dotąd nie podjęła ona tego wyzwania i nie rozpoczęła obrony swoich teorii na forum naukowym.

Niewątpliwie Maciej Giertych w swojej publicystyce dotyczącej masońskich koncepcji integracji europejskiej wcielił się w rolę advocatus diaboli. Z jednej strony emocjonalnie angażuje się w udowodnienie naukowego charakteru teorii masońskich, wypierając niejako teorie naukowe, choćby istniejące na gruncie europeistyki. W ten sposób przydaje splendoru masonerii - w swoisty sposób udowadniając jej sprawstwo w przypadku procesu integracji europejskiej, co wydaje się być przesadą. Koncepcje masońskie w swej przeważającej mierze nigdy nie wyszły poza obszar subdyscypliny naukowej - masologii, jak również nie zasiliły w sposób znaczący innych nauk humanistycznych i społecznych.

Maciej Giertych jest postrzegany jako osoba pełniąca kierownicze role w organizacjach narodowych, w tym w Lidze Polskich Rodzin, dlatego dla laika może wydawać się jego rola entuzjasty masońskiej koncepcji integracji europejskiej jako co najmniej niezrozumiała. Przyjmując rolę advocatus diaboli, uzyskuje on dwie zamierzone korzyści: po pierwsze poddaje krytyce proces 
integracji europejskiej, której sprawstwo przypisuje masonerii, a nie powszechnie uznanym autorytetom ze świata nauki i polityki. W ten sposób, w swoim mniemaniu, deprecjonuje znaczenie integracji. Po drugie swoimi artykułami nadaje rozgłos teoriom masońskim, na którym aż tak bardzo masonerii nie zależy. Taka taktyka publicystyczna ze strony Macieja Giertycha wynika również z faktu, że środowiska narodowe, w tym Liga Polskich Rodzin, uważają, że „udział Polski w UE nie byłby zagrożeniem dla suwerenności zdaniem liderów Ligi, gdyby UE była organizacją na wzór EWG. Unia Europejska zmierzająca w kierunku federacji na wzór Stanów Zjednoczonych w Europie staje się destrukcyjna dla państw narodowych, łamie ich suwerenność. Istotnym zagrożeniem jest również doktryna wielokulturowości. Dlatego UE była postrzegana przez członków LPR jako narzędzie destrukcji narodowości i państwowości. Narodowość przeszkadza w tworzeniu homogenicznego organizmu europejskiego. Największymi zagrożeniami dla państw narodowych były także według Ligi: laicyzacja i respektowanie dyrektyw UE oraz orzeczeń strasburskich" (Płoski, 2016b).

To co łączy masonerię i organizacje mafijne to ich półtajny, sekretny charakter. Dlatego odwołam się do przykładu z serialowej fabuły, obrazującego sytuację, w jakiej znalazł się Maciej Giertych. W latach 80 . XX wieku ogromnym powodzeniem u telewidzów cieszył się włoski serial mafijny Ośmiornica, emitowany w telewizji publicznej. Fabuła tego serialu sprowadza się do walki dzielnego i bezkompromisowego komisarza Corrado Cattaniego - w którego wcielił się Michele Placido - z organizacją mafijną. Komisarz Corrado Cattani jest już bliski skompletowania wszystkich dowodów przeciwko mafijnym bossom, ale cały czas brakuje mu kluczowych zeznań świadków, co wynika z sekretnego charakteru organizacji mafijnej. Wtedy zrozpaczony komisarz Cattani stwierdza, że jego działania wymierzone przeciwko mafii to w istocie „walka z cieniami”. Maciej Giertych w swojej publicystyce walczy właśnie z 'cieniami'. Nie da się uprawiać nauki, tworzyć koncepcji naukowych, wymieniać myśli, gdy interlokutorem jest 'cień', jakaś 'bliżej niezidentyfikowana osoba z organizacji masońskiej', jakaś 'obediencja masońska'.

Maciej Giertych podjął się bardzo ambitnego przedsięwzięcia naukowego, a mianowicie starał się udowodnić naukowy charakter koncepcji masońskich dotyczących Stanów Zjednoczonych Europy oraz wykazać, iż to w zasadzie masoneria była siłą sprawczą w przypadku integracji europejskiej. Z tych zadań Maciej Giertych się nie wywiązał, ponieważ są one karkołomne i niewykonalne na gruncie nauki. 
BibLIOGRAFIA:

Baszkiewicz, J. (1990). Danton. Warszawa: Państwowy Instytut Wydawniczy.

Białas-Zielińska, K. (2011). Zjednoczona Europa w myśli Konrada Adenauera, Roberta Schumana oraz Alcide de Gasperiego. Zarys problematyki. Acta Erasmiana, 1, 39. Pobrane z: http://www.repozytorium.uni.wroc.pl/dlibra/docmetadata?i$\mathrm{d}=40881 \&$ from $=\&$ dirids $=85 \&$ ver_id $=\& l \mathrm{l}=1 \& \mathrm{QI}=$

Chrisidu-Budnik, A., Korczak, J., (2013). Województwo jako kreator rozwoju regionalnego. Pobrane z: http://www.repozytorium.uni.wroc.pl/dlibra/docmetadata?i$\mathrm{d}=42899 \&$ from $=\&$ dirids $=85 \&$ ver_id $=\& \mathrm{lp}=1 \& \mathrm{QI}=$

de Lassus, A. (1993). Masoneria - intrygująca tajemniczość. Paryż: Wydawnictwo Ruch na rzecz rodziny i szkoły.

de Poncins, L. (1942). La franc-maconnerie d'apres ses docu-ments secrets. Chiré: Montreuil.

Giertych, M. (1997). Europa regionów. Opoka w Kraju, 24(45).

Giertych, M. (1998). Notatki: W Europie. Opoka w Kraju, 25(46).

Giertych, M. (2003a). Notatki: Francja, córa masonerii. Opoka w Kraju, 46(67).

Giertych, M. (2003b). Korzenie UE. Opoka w Kraju, 44(65).

Giertych, M. (2003c). Korzenie UE. Opoka w Kraju, 31(52).

Giertych, M. (2004). Umazać Kościół. Opoka w Kraju, 48(69).

Giertych, M. (2005). Co to jest program narodowo-katolicki? Opoka w Kraju, 55(76).

Giertych, M. (2009). Notatki: Unia a masoneria. Opoka w Kraju, 69(90).

Giertych, M. (2010). Notatki: Z Masonami. Opoka w Kraju, 74(95).

Grabowiec, P. (1998). Od partykularyzmu do uniwersalizmu. Polskie koncepcje międzynarodowej integracji politycznej w latach 1939-1945. Zarys problematyki. W: W. Bokajło (red.). Federalizm: teorie i koncepcje (s. 237-238). Wrocław: Wydawnictwo Uniwersytetu Wrocławskiego.

Hass, L. (1993). Masoneria polska XX wieku: losy, loże, ludzie. Warszawa: Oficyna Wydawnicza POLCZEK. Hausknecht, M. (1962). The Joiners: A Sociological Description of Voluntary Associations Membership in United States. New York: Bedminster Press.

Malinowski, B. (1958). Szkice z teorii kultury. tłum. H. Buczyńska i in., Warszawa: Wydawnictwo Książka i Wiedza.

Ousset, J. (1986). Pour qu'Il regne. Bouère: DMM (Dominique Martin Morin Editions). Płoski, M. (2016a). Państwo narodowe wobec procesu globalizacji i integracji. W: Z. Zagórski, S. Kamykowski (red.). (Nie)ład a (od)budowa cywilizacji (s. 176). Wrocław: Wydawnictwo Uniwersytetu Wrocławskiego.

Płoski, M. (2016b). Liga Polskich Rodzin jako aktor społeczny. Pobrane: http://www. repozytorium.uni.wroc.pl/publication/80114.

„Points de vue initiatiques” (Inicjatycznepunkty widzenia) Wielkiej Loży Francji 1989, nr 71.

„Points de vue initiatiques” (Inicjatycznepunkty widzenia) Wielkiej Loży Francji 1989, nr 72.

Virion, P. (1999). Rząd światowy: globalizm, antykościół i superkościół. tłum. Henryk Czepułkowski. Komorów: Wydawnictwo Antyk Marcin Dybowski. 